\title{
Die rol van Ou Testament Teologie in die prediking
}

G T M Prinsloo

\section{ABSTRACT}

The function of Old Testament Theology in preaching

While preparing a sermon from the Old Testament, pastors often tend to neglect the important role that Old Testament Theology can play in assisting them to apply the ancient text to modern circumstances. In this paper, two reasons for this neglect is discussed, namely the problems concerning the method, task and scope of Old Testament Theology on the one hand and the inadequate historical and literary skills of the exegete on the other hand. Solutions to both problem areas are proposed. The conclusion is reached that Old Testament Theology should play a definite role in preparing a sermon. It functions as bridge between a specific text and today. As such it should guide the exegete in his effort to apply Old Testament texts to circumstances at the end of the twentieth century. The theoretical considerations is illustrated by an example (Numbers 19:1-22).

1

INLEIDING

Daar bestaan min twyfel dat Ou Testament Teologie in die oë van die deursnee predikant as die stiefkind van die Ou-Testamentiese wetenskap beskou word. In die moeisame proses van eksegese en preekvoorbereiding sal 'n predikant nog tyd inruim om 'n geskiedenis van die Ou-Testamentiese tydvak te raadpleeg, hy/sy sal kommentare uit verskillende eksegetiese tradisies bestudeer en uit goeie inleidings op hoogte kom van die problematiek van 'n spesifieke boek of die opbou van die boek. Die kans is goed dat 'n predikant die sosio-kulturele agtergrond van 'n teks sal navors. Dit is egter te betwyfel of 'n predikant die moeite sal doen om 'n Teologie van die Ou Testament te bestudeer.

Dit is 'n baie ongelukkige toedrag van sake, want die versuim om 'n teks teen die agtergond van die Teologie van die Ou Testament te bestudeer, is nie alleen 'n verskraling van die eksegetiese proses nie, maar impliseer ook die verlies van 'n onontbeerlike hulpmiddel om die boodskap van 'n teks te konkretiseer vir die gemeente.

Ou Testament Teologie kan 'n belangrike rol in die prediking speel. Dit behoort die breë teologiese raamwerk te verskaf waarteen die eksegeet die teks interpreteer. Verder behoort dit die eksegeet deur die eksegetiese proses te begelei 
en hom te help om by sy einddoel, naamlik 'n preek vir vandag, uit te kom. Daar is egter goeie redes waarom hierdie ideaal in die praktyk nie bereik word nie. Aan die een kant lê die probleem by die Teologie van die Ou Testament self. Die wetenskap lyk op die oog af na 'n warboel van onversoenbare standpunte. Aan die ander kant lê die probleem by die eksegeet wat nie in staat is om teks en teologie, eksegese en sentrale boodskap, by mekaar uit te bring nie. Die doel van hierdie artikel is om hierdie twee probleemareas kortliks te belig, aan die hand daarvan die plek van Ou Testament Teologie in die prediking te bepaal en die teorie met 'n praktiese voorbeeld te illustreer.

Die ongewildheid van Ou Testament Teologie is deels te wyte aan die talle probleemareas wat, ten spyte van 'n magdom publikasies, nog onopgelos bly. Die belangrikste probleemareas word in die volgende paragrawe kortliks aan die orde gestel.

\subsection{Dogmatiek, Bybelse Teologie en Ou Testament Teologie}

Ou Testament Teologie is ' $n$ wetenskap met ' $n$ lang geskiedenis. Daar kan nie in besonderhede op hierdie veelbewoë geskiedenis ingegaan word nie'. Bybelse Teologie het gedurende die sestiende eeu ontstaan as die wetenskap wat die dicta probantia of Skriftuurlike bewysplase vir die sisteme van die Dogmatiek moes verskaf ${ }^{2}$. Bybelse Teologie het hierdie ondergeskikte rol gespeel tot en met die intreerede van J P Gabler op 30 Maart 17873. Dit kan (weliswaar gekwalifiseerd ${ }^{4}$ ) beskou word as die geboortedatum van Bybelse Teologie as 'n selfstandige historiese wetenskap naas die Dogmatiek en onafhanklik daarvan ${ }^{5}$. Volgens Gabler lê die uniekheid van Bybelse Teologie juis in die historiese karakter daarvan. Toegepas op die Ou Testament beteken dit dat die dissipline onlosmaaklik verbind is aan die geskiedenis van Israel en die historiese groeiproses van die Ou Testament. Dit impliseer dat die ontwikkelingsgang van die Ou-Testamentiese geskiedenis deur middel van die histories-kritiese metode vasgestel en die teologiese relevansie daarvan bepaal moet word6.

Die positiewe sy van Gabler se insigte is dat hy die Ou Testament Teologie losgemaak het van sy minderwaardige posisie teenoor Dogmatiek. Tog het die probleem van $\mathrm{Ou}$ Testament Teologie by geboorte reeds beslag gekry in die definisie van die dissipline as 'n historiese dissipline. Dit het aanleiding gegee tot twee uiteenlopende standpunte oor hoe teologie bedryf moet word. Enersyds is daar die standpunt dat Ou Testament Teologie uit en uit 'n historiese dissipline is, 
dat 'n Teologie van die Ou Testament niks meer kan wees as 'n godsdiensgeskiedenis van Israel nie. In reaksie hierop is daar diegene wat Ou Testament Teologie bedryf vanuit ' $n$ voorgestelde Mitte of middelpunt en die hele Ou Testament by so 'n keurslyf probeer inpas. Dit lei onmiddellik tot 'n derde probleem, naamlik die verhouding tussen Ou en Nuwe Testament. Hierdie drie probleemareas kan nie in die bestek van hierdie artikel volledig behandel word nie? ${ }^{7}$. Slegs die breë ontwikkelingstendense word aangetoon.

\subsection{Ou Testament Teologie, heilsgeskiedenis en godsdiensgeskiedenis ${ }^{8}$}

Die eerste probleemarea in Ou Testament Teologie is die vraag hoe ver Gabler se definisie van Ou Testament Teologie as 'n historiese dissipline gevoer moet word. Indien die geskiedenis van Israel die sleutel tot die interpretasie van die teologie word, word 'n Teologie van die Ou Testament dikwels niks meer as 'n godsdiensgeskiedenis van Israel nie.

Die belangrikste verteenwoordiger van die standpunt dat ' $n$ Teologie van die Ou Testament die geskiedenis as vertrekpunt moet neem, is Gerhard von Rad. In sy magistrale Theologie des Alten Testaments' ${ }^{9}$ maak Von Rad 'n onderskeid tussen die geskiedenis van Israel soos dit deur die histories-kritiese wetenskap gerekonstrueer word en die weergawe van die geskiedenis soos gesien deur die geloofsoog van die Israeliet. Die eerste weergawe werk met die kritiese minimum, die tweede met die teologiese maksimum ${ }^{10}$. Die taak van Ou Testament Teologie is om die gang van die tweede moontlikheid, naamlik die geskiedenis van Israel deur die oë van geloof, na te vors'11. Von Rad se teologie kan beskryf word as 'n teologie van Israel se historiese en profetiese tradisies wat telkens in opeenvolgende geslagte geherinterpreteer is ${ }^{12}$. Deur die Nacherzählung van die tradisies kry die Heilsgeschichte gestalte. Ten spyte van die baie positiewe dinge wat oor Von Rad se werk gesê kan word, bly een groot leemte dat sy teologie dikwels niks meer is as 'n godsdiensgeskiedenis van Israel nie ${ }^{13}$. Groot korpusse in die Ou Testament wat nie 'n historiese inslag het nie, byvoorbeeld die wysheidsliteratuur en kultiese tekste, word gevolglik afgeskeep ${ }^{14}$.

Von Rad het talle navolgers gevind. Om maar een resente voorbeeld te noem, word verwys na die teologie van Gunneweg 15 . Hy voer aan dat die geskiedenis en teologie van ou Israel onlosmaaklik aan mekaar verbind is. Sy "Bybelse Teologie" word bloot 'n weergawe van Israel se godsdiensgeskiedenis vanaf die voor-Israelitiese godsdienstige strominge in Palestina tot by die laat na-eksiliese tyd. Die debat oor die rol van geskiedenis in 'n Teologie van die Ou Testament woed heftig voort. 
Hoewel dit waar is dat die Ou Testament ' $n$ historiese karakter het en onlosmaaklik verbind is aan die wedervaringe van die volk Israel, vervul 'n blote godsdiensgeskiedenis nie die rol van 'n Teologie nie. Indien Ou Testament Teologie relevant wil wees vir 'n predikant wat 'n teks op vandag se situasie moet toepas, moet dit op die ou einde meer wees as 'n "history of revelation", 'n "history of religion" of 'n "history of tradition"16.

\subsection{Die sentrale tema van die Ou Testament ${ }^{17}$}

In reaksie teen die gevaar dat 'n Teologie van die Ou Testament bloot 'n godsdiensgeskiedenis word, is aangevoer dat die Ou Testament 'n middelpunt of sentrale tema het waarby alle tekste aansluit. Hierdie ontwikkeling het onmiddellik die tweede probleemarea in die Ou Testament Teologie geword.

As verteenwoordiger van die tweede groep geld die ewe indrukwekkende Theologie des Alten Testaments van Walther Eichrodt 18 . Eichrodt probeer wegbeweeg van die oordrewe klem op die geskiedenis ${ }^{19}$ en stel 'n sentrale tema voor as bril waardeur die Ou Testament gelees moet word. Die tema wat hy kies is die verbond 20 . Alle tekste kan vanuit hierdie tema verklaar word ${ }^{21}$. Deur die formulering van 'n sentrale tema gee Eichrodt aan die eksegeet 'n sleutel waarmee die boodskap van Ou-Testamentiese tekste oopgesluit kan word. In dié sin is sy benadering veel meer "gebruikersuriendelik" as dié van Von Rad. Tog moet ernstige vraagtekens agter sy benadering geplaas word. Hoewel die begrip verbond 'n belangrike rol in die Ou Testament speel, is dit ' $n$ vraag of die skema omvattend genoeg is om die totale Ou Testament te omvat. Die feit dat Eichrodt die wysheidsliteratuur skaars aanraak, is 'n duidelike bewys dat sy skema nie omvattend genoeg is om alle Ou-Testamentiese tekste te dek nie ${ }^{22}$.

Eichrodt het talle navolgers gevind wat (dikwels uiteenlopende) sentrale temas vir die Ou Testament voorgestel het. Sellin ${ }^{23}$ stel byvoorbeeld die "heiligheid van God" voor as sentrale tema, Köhler ${ }^{24}$ verkies die tema "God is Lord", Vriezen ${ }^{25}$ werk met die begrip "gemeenskap" en Kaiser ${ }^{26}$ met die begrip "blessing-promise". Talle teoloë het aangevoel dat 'n enkele tema nie in staat is om die diverse karakter van die Ou Testament te omskryf nie. Daarom verkies hulle meer uitgebreide temas, byvoorbeeld 'Jahwe die God van Israel, Israel die volk van Jahwe'27, die eerste gebod ${ }^{28}$, die frase "Ek is die Here jou God"29, die "Tora"30 of selfs die boek Deuteronomium ${ }^{31}$. Tot hierdie groep kan ook dié teoloë gereken word wat twee parallelle of dialektiese begrippe as sentrum van die Ou Testament voorstel, byvoorbeeld die dialektiek tussen die etiese en die estetiese ${ }^{32}$, die woordpaar "Gottesherrschaft/Gottesgemeinschaft" 33 of die parallelle woordpaar "rettende Gott/segnende Gott"34. In sy resente teologie voer Preuss 35 aan dat 'n statiese 
begrip nie daarin kan slaag om die essensie van die Ou Testament te omskryf nie. Die tema van die Ou Testament moet gesoek word in dinamiese en aktiewe begrip wat God se handelinge met die wêreld en sy volk tot uitdrukking bring. Volgens hom is die uitverkiesing van Israel só 'n aktiewe begrip en dit word by hom die sentrum van die Ou Testament ${ }^{36}$.

Die vernaamste kritiek teen al hierdie pogings om die Teologie van die Ou Testament te reduseer tot 'n sentrale boodskap, is dat daardie sentrum noodwendig afgedwing moet word op uiteenlopende literatuur wat oor 'n lang tydperk ontstaan het. Die gekose sentrum is alleen geskik vir materiaal wat binne daardie skema ingepas kan word. Alles wat buite die skema val, word onbevredigend behandel ${ }^{37}$. Hierdie skemas bied dus geen oplossing vir die eksegeet wat die teologie van 'n spesifieke teks vir vandag moet bepaal nie.

\subsection{Die verhouding tussen die Ou- en Nuwe Testament}

Die noodwendige gevolg van Gabler se onderskeid tussen Bybelse Teologie en Dogmatiek met die gepaardgaande beklemtoning van die historiese karakter van Bybelse Teologie, was dat Ou- en Nuwe Testament Teologie ook van mekaar geskei sou word. Dit het reeds in 1796 gebeur met die publikasie van G L Bauer se Theologie des Alten Testaments 38 . Dit het onmiddellik die probleem van die verhouding tussen die Ou- en Nuwe Testament na vore geroep.

Hierdie probleem het 'n baie lang geskiedenis ${ }^{39}$. Die sienings van Marcion wat die Ou Testament beskryf het as 'n minderwaardige boek wat handel oor 'n wrede God, 'n boek wat nie in die Christelike kanon tuishoort nie, is baie bekend ${ }^{40}$. Die twee klassieke brûe tussen die Ou- en Nuwe Testament is die tipologie en allegorie. Ten grondslag van beide lê die siening dat die Ou Testament beloftes bevat, die Nuwe Testament die vervulling van daardie beloftes. Volgens die tipologiese verklaring bevat die Ou Testament antitipes wat eers deur die tipe in die Nuwe Testament tot volle verwerkliking kom ${ }^{41}$. In 'n sekere sin hou die tipologiese benadering nog vas aan die historiese konteks van die Ou Testament. By die allegoriese interpretasie word die historiese basis egter verruil vir die sogenaamde "dieper" of "geestelike" betekenis van Ou-Testamentiese tekste. Die boodskap van die Ou-Testamentiese teks as sodanig is nie belangrik nie, die dieper betekenis wel ${ }^{42}$. In beide benaderings word die Ou Testament gereduseer tot 'n minder belangrike boek wat eers werklik in die lig van die Nuwe Testament betekenis kry. Ten spyte van eeue se nadenke oor die Ou Testament, is die allegoriese of tipologiese uitleg vandag steeds 'n gewilde wyse om die Ou Testament te verklaar. Dit word duidelik in die aandrang dat Ou-Testamentiese tekste ten alle koste Christologies geinterpreteer moet word. 
Die debat oor die verhouding tussen Ou en Nuwe Testament bly steeds heftig. Twee uiteenlopende benaderings word gevolg. Enersyds word die kontras en diskontinü̈teit tussen Ou en Nuwe Testament beklemtoon. Andersyds word die eenheid en kontinuiteit uitgewys ${ }^{43}$. Die eerste groep word verteenwoordig deur teoloë wat die Ou Testament afmaak as 'n minderwaardige boek wat gegroei het uit 'n nie-Christelike godsdiens en dus nie werklik vir Christene relevant is nie. Die Ou Testament is 'n boek van mislukkings wat alleen vir 'n Christen relevansie het in soverre dit hom bewus maak van die groot behoefte aan verlossing deur Christus ${ }^{44}$. Die ander uiterste word egter ook soms beklemtoon, naamlik dat die Ou Testament as die belangrikste openbaring van God beskou moet word. Dit is die "eintlike" Bybel, terwyl die Nuwe Testament niks meer is as 'n verklarende appendiks by die Ou Testament nie ${ }^{45}$. Nóg 'n onderwaardering nóg 'n oorwaardering van die Ou Testament bied egter 'n bevredigende verklaring vir die probleem van die verhouding tussen Ou en Nuwe Testament. Die oplossing moet langs ander weë gevind word.

Von Rad 46 beskryf die verhouding tussen Ou en Nuwe Testament in terme van tipologie. Von Rad wyk egter af van die klassieke aanhangers van tipologie daarin dat hy alles in die Ou Testament nie reduseer tot voorafskadu's van Christus nie, maar tot analoë handelinge van God in die Ou en Nuwe Testament. Die klassieke belofte-vervulling skema vind ook moderne aanhangers in byvoorbeeld Westermann ${ }^{47}$ en Zimmerli48. Dit is egter ook 'n gekwalifiseerde gebruik van die skema waarin erken word dat alles in die Ou Testament nie gereduseer kan word tot belofte en alles in die Nuwe Testament tot vervulling nie. Die pogings van Von Rad, Westermann en Zimmerli is belangrike wegwysers op die pad om die probleem op te los, maar reduseer nog te dikwels die Ou Testament tot 'n minderwaardige boek ${ }^{49}$.

Die problematiek van die verhouding tussen Ou en Nuwe Testament word veral akuut in resente pogings om 'n Bybelse Teologie tot stand te bring50. Enersyds word die verhouding tussen Ou en Nuwe Testament gesien as 'n diakroniese groeiproses waar die tradisie-historiese proses wat in die Ou Testament begin het in die Nuwe Testament afgesluit word. Dit is byvoorbeeld die standpunt van Gese 51 . Die eenheid tussen Ou en Nuwe Testament lê in die historiese groeiproses. Bybelse Teologie moet hierdie eenheid, wat in die historiese proses opgesluit lê, ontsluit ${ }^{52}$. Presies die teenoorgestelde word gedoen deur Childs 53 . Hy is een van die mees prominente voorstanders van 'n Bybelse Teologie ${ }^{54}$. Die kanon van die Christelike Kerk is volgens hom die band wat die twee Testamente saambind 55 . Hy wys die diakroniese metode af, werk met die finale vorm van die teks ${ }^{56}$ en dui aan dat slegs die kanoniese konteks normatief is vir Bybelse Teologie ${ }^{57}$. In sy teologie ${ }^{58}$ bepleit Childs ' $n$ kanoniese benadering tot Ou Testament Teologie ${ }^{59}$ waarin die Bybelse 
teks die promimente rol speel en nie die geskiedenis wat agter die tekste lê nie. 'n Teologie van die Ou Testament is primêr 'n Christelike onderneming, daarom moet by die Nuwe Testament uitgekom word ${ }^{60}$. Childs ${ }^{61}$ illustreer sy benadering prakties in sy resente Bybelse teologie. Hy bepleit weereens 'n kanoniese benadering tot Bybelse teologie ${ }^{62}$. Dit word gevolg deur 'n bespreking van die teologiese inhoud van die verskillende boeke van die Ou en Nuwe Testamente en deur 'n sistematiese bespreking van belangrike temas in die "Christian Bible". 'n Soortgelyke benadering word bepleit deur Clements ${ }^{63}$ en Rendtorff 64 .

Uit bogenoemde bespreking is dit duidelik dat daar ook oor die vraag na die verhouding tussen die twee dele van die Skrif geen eenstemmigheid bestaan nie. Hase ${ }^{65}$ dui aan dat die verhouding 'n komplekse een is wat waarskynlik nooit met 'n enkele kategorie verklaar sal kan word nie. Dit behoort ook as waarskuwing vir die pastor te dien om nie oorvereenvoudigde skemas te gebruik en sodoende die boodskap van die Skrif te verskraal nie.

\subsection{Samevatting}

Uit bogenoemde bespreking is dit duidelik dat die problematiek van Ou Testament Teologie tot op hede nie opgeklaar is nie. Ten spyte van 'n magdom publikasies bly onsekerheid oor elke probleemarea bestaan. Met elke nuwe publikasie word die verwarring skynbaar groter! Wie kan dus 'n predikant kwalik neem as hy sy hande in die lug gooi en sonder Ou Testament Teologie probeer klaarkom?

\section{3}

\section{TEOLOGIE EN EKSEGESE}

Die ongewildheid van Ou Testament Teologie kan egter nie net aan onsekerheid oor die aard en taak van die dissipline toegeskryf word nie. Ook die eksegeet moet deel van die blaam dra. In die volgende paragrawe word veral twee terreine uitgewys waar die predikant fouteer.

\section{1 'n Gebrekkige historiese bewussyn}

Dikwels word die Ou Testament deur eksegete benader met 'n gebrekkige historiese bewussyn. Alle tekste in die Skrif word eenvoudig op presies dieselfde lyn geplaas. Tekste in Openbaring word met die grootste gemak in verband gebring met tekste in Genesis, asof die Bybel op 'n goeie dag pasklaar op aarde beland het. Die eksegeet is nie in staat om die gekose teks te plaas teen die historiese, kulturele en sosiale agtergrond van Ou Israel nie. Gevolglik is hy/sy ook nie in staat om die teologiese drakrag van die teks te bepaal nie ${ }^{66}$. 
Die gevolg van so 'n eksegetiese benadering is dat die Bybel 'n oneindige ensiklopedie van bewysplase word, 'n towerkissie warin die eksegeet sy hand steek en triomfantelik kitsoplossings vir elke lewenssituasie aanbied. Vir die eksegese van die Ou Testament het dit verwoestende gevolge. Die Ou Testament word of totaal irrelevant of enige teks in die Ou Testament word gedwonge Christologies geïnterpreteer sonder inagneming van die boodskap van die teks binne die konteks van die Ou Testament. Watter moontlikheid ook al gekies word, die eie waarde van die Ou Testament as deel van die Christelike kanon word misken. Gevolglik word die boodskap van die Ou Testament gereduseer tot dit wat direk op die Nuwe Testament van toepassing gemaak kan word.

Die eindresultaat van hierdie benadering is dat die teoloog Ou Testament Teologie as oorbodig beskou. Wie het dan nou Ou Testament Teologie nodig as die Ou Testament irrelevant geword het vir die moderne Christen?

\section{2}

\section{'n Gebrekkige literêre bewussyn}

Verwant aan bogenoemde is die tweede probleem, naamlik 'n gebrekkige literêre bewussyn. Daarmee word bedoel dat die Ou Testament dikwels geïnterpreteer word sonder ' $n$ weldeurdagte eksegetiese metodiek wat reg laat geskied aan die literêre karakter van die Ou Testament en sonder inagneming van die literatuursoort waarmee gewerk word. Weer eens word alle tekste op presies dieselfde lyn geplaas. Barton ${ }^{67}$ het aangedui dat ' $n$ literêre kompetensie noodsaaklik is vir die verstaan van tekste. Veral twee komponente is belangrik by 'n literêre kompetensie. Die eerste is die vermoë om die literatuur van die Ou Testament met gemak en met selfvertroue te kan hanteer. Grondige eksegese gebaseer op gesonde wetenskaplike beginsels is onontbeerlik vir die korrekte verstaan van die $\mathrm{Ou}$ Testament. Grondige eksegese veronderstel onder andere die vermoë om die $\mathrm{Ou}$ Testament in die Hebreeus/Aramees te kan analiseer en interpreteer. Die tweede is die vermoë om die genre van 'n teks te bepaal en die teks binne die kader van daardie genre te interpreteer. Verskillende reëls geld vir verskillende tipes literatuur. Wie dit misken, kan die teks nie korrek interpreteer nie.

Die eksegeet wat nie oor 'n basiese literêre kompetensie beskik nie, kan nie 'n teks teen sy sosio-kulturele agtergrond interpreteer en die teologiese relevansie daarvan bepaal nie. Die resultaat hiervan is dat die Nuwe Testament in die Ou Testament ingelees word en dat dit op die ou einde irrelevant word om die presiese boodskap van 'n Ou-Testamentiese teks te bepaal. Ou Testament Teologie word 'n dissipline wat oorgelaat kan word aan 'n paar ingewydes wat nie nodig het om rekening te hou met die werklikheid van die bediening nie. 
In die praktyk beteken dit dat 'n predikant wat nie oor basiese eksegetiese vaardighede beskik nie en nie op grond van sy kennis van Hebreeus ten minste verantwoordbare besluite oor 'n teks kan neem en verantwoordelike uitsprake oor 'n teks kan maak nie, ook nie in staat is om die teologie van 'n teks te bepaal nie. Vir so 'n predikant word Ou Testament Teologie uit die aard van die saak oorbodig.

\subsection{Samevatting}

Die versuim van die eksegeet om erns te maak met die teks van die Ou Testament lei dikwels daartoe dat die Ou Testament afgeskeep word en die boodskap daarvan verskraal word. Ou Testament Teologie word oorbodig as die Ou Testament nie as selfstandige deel van die Skrif tot sy reg kom nie.

\section{'N UITWEG UIT DIE DOOLHOF}

Die vraag ontstaan onmiddelik of daar 'n uitweg uit die doolhof van probleme bestaan. Die hipotese in hierdie studie is dat 'n uitweg uit beide probleemareas moontlik is.

\subsection{Teologie, teologieë en 'n breë teologiese raamwerk}

Van die kant van die Ou Testament Teologie lê die oplossing in 'n nuwe benadering tot die dissipline. Die geskiedenis het reeds bewys dat nóg 'n poging tot 'n eng geformuleerde sentrale tema, nóg 'n teologie wat bloot 'n godsdiensgeskiedenis word, as 'n volledige teologie van die Ou Testament beskou kan word.

Die uitweg lê daarin om die teologie van afsonderlike boeke te bepaal, boeke te groepeer in verhaalkomplekse of ander groter literêre eenhede en die teologie daarvan te bepaal en alles uiteindelik te plaas binne 'n breë teologiese raamwerk waarin die relasie tussen die verskillende motiewe, temas en teologiese konsepte elkeen tot sy reg kan kom $^{68}$. Die resultaat hiervan sal wees dat daar eerder van teologieë van die Ou Testament as die Teologie van die Ou Testament gepraat behoort te word ${ }^{69}$. Die voordeel van so 'n benadering is dat elke boek en literêre kompilasie in die Ou Testament tot sy reg kan kom. Eers wanneer die teologieë van die Ou Testament langs hierdie weg in hulle volle diversiteit aan die orde gestel is, kan daar na deurlopende temas gesoek word ${ }^{70}$.

Die vraag na die uiteindelike sentrale en saambindende tema kan hier slegs teoreties beantwoord word. Ideaal gesproke moet elke boek van die $\mathrm{Ou}$ Testament eers volledig geëksegetiseer word voordat hierdie vraag aan die orde gestel kan word. Daarom moet eerder gedink word aan 'n breë teologiese 
raamwerk as 'n enkele sentrale tema. Die raamwerk moet werklik breed wees, anders word die probleem van die middelpunt van die Ou Testament net voortgesit $^{71}$. Hasel ${ }^{72}$ wys daarop dat die Ou Testament primêr teosentries is. God se betrokkenheid by mense en volke, by die skepping en die natuur, by die geskiedenis van die wêreld en sy volk loop soos 'n goue draad deur elke boek van die $\mathrm{Ou}$ Testament en word in die Nuwe Testament voortgesit. Ten spyte van die verskil in beklemtoning, die ryke skakerings van uitdrukking en die diversiteit van situasies, wil alle tekste van die Ou Testament iets sê oor God se betrokkenheid by die wêreld en die mens. 'n Predikant kan dus verwag dat elke teks in die Ou Testament, hoe vreemd dit ook al vir die moderne leser mag voorkom, iets oor God se betrokkenheid by die wêreld wil vertel. Natuurlik sal elke teks 'n unieke blik op hierdie betrokkenheid bied. Die uitdaging is juis om elke teks die geleentheid te bied om sy eie unieke perspektief aan te bied en dan te vra watter implikasies dit vir vandag het.

'n Breë teologiese raamwerk kan ook dien as oplossing vir die probleem van die verhouding tussen die Ou- en die Nuwe Testament. Wanneer die perspektief oopgaan dat die God van die Ou en die Nuwe Testament dieselfde God is, verval die behoefte aan 'n gedwonge Christologiese interpretasie van die Ou Testament ${ }^{73}$. Met God as sentrum van die Ou en die Nuwe Testament kan werklik uiting gegee word aan die veelkantigheid van sy betrokkenheid by die wêreld. Met hierdie breë teologiese raamwerk in gedagte kan op verantwoordelike wyse gewys word op analoë tussen die twee Testamente.

In die praktyk beteken dit dat daar 'n groot verantwoordelikheid op die skouers van die predikant geplaas word. 'n Teologie soos hierbo beskryf is, bestaan eenvoudig nie. Elke predikant moet as't ware sy eie teologie maak wanneer hy/sy uit die Ou Testament preek. Met die raamwerk as riglyn is dit egter geen onmoontlike taak nie.

\subsection{Teologie, teologieē en die skopus van die teks}

Van die kant van die eksegeet lê die oplossing in sinvolle, deeglike en volledige eksegese van die gekose perikoop. Teologie kan op geen ander plek begin as by die eksegese van individuele tekste nie ${ }^{74}$. Die vaardigheid van 'n predikant word deur 'n Ou-Testamentiese teks tot die uiterste beproef. Eksegese is dikwels moeisame werk, maar niks kan deeglike eksegese vervang nie. Ou Testament Teologie begin by die bepaling van die boodskap, die teologiese skopus van die teks. Van daar af behoort die eksegeet die teks te interpreteer teen die agtergrond van die teologie van die onmiddellike konteks, die boek, groter literêre komplekse, die Ou Testament, die Nuwe Testament en die hedendaagse situasie. Dit alles moet 
geskied met inagneming van die teks se historiese agtergrond en die literatuursoort van die teks.

Die logiese vertrekpunt in die bepaling van die teologie is om te vra na die kern, die beginsel, die skopus van die betrokke teks. Wanneer daardie beginsel geplaas word teen die agtergrond van die breë teologiese raamwerk van God se betrokkenheid by die wêreld, word dit meteens veel makliker om na die Nuwe Testament en vandag oor te gaan. Die Ou Testament word nie in 'n keurslyf ingedwing nie, maar elke teks word toegelaat om op sy unieke wyse perspektief te bring op dié God wat met sy mense en sy wêreld besig is. So kan die eksegeet op verantwoordbare wyse die teks vir vandag interpreteer.

\section{$4 \quad$ BRUG TUSSEN TEKS EN PREEK}

Uiteindelik kan die vraag gevra word: Wat is die verhouding tussen eksegese, teologie en prediking? Teologie speel 'n besliste rol (of ten minste: behoort 'n besliste rol te speel) in die prediking75. Die Ou Testament was belangrik in die prediking van die Nuwe Testament. Deur toepassing en herinterpretasie is die boodskap van die Ou Testament relevant gemaak vir 'n nuwe situasie. Vandag behoort die taak van Ou Testament Teologie steeds te wees om die teologiese relevansie van 'n teks, korpus of van die Ou Testament in sy geheel uit te wys ${ }^{76}$.

Dit is egter ewe waar dat Ou Testament Teologie 'n rol speel (of behoort te speel) in die eksegetiese proses 77 . Daar bestaan geen eenstemmigheid oor die presiese aard van hierdie rol nie. Soms word Teologie bo eksegese geplaas, soms eksegese bo Teologie, soms word die wederkerige verhouding tussen eksegese en Teologie beklemtoon ${ }^{78}$. Hasel ${ }^{79}$ beklemtoon dat eksegese en teologie onlosmaaklik aan mekaar verbonde is. Aan die een kant veronderstel 'n Teologie van die $\mathrm{Ou}$ Testament deeglike eksegese, aan die ander kant kan 'n teks nie volledig geïnterpreteer word sonder 'n teologiese prespektief nie.

In die lig van alles wat gesê is, moet gekonkludeer word dat Ou Testament Teologie onmisbaar is vir sowel die eksegese as die prediking. Teologie kan met reg beskou word as die brug tussen teks en preek. Teologie bepaal die raamwerk waarteen die teks geinterpreteer word en dui die rigting aan waarheen beweeg moet word. Teologie word'n onmisbare skakel in die konkretisering van die boodskap van destyds vir die mense van vandag. Skematies kan die rol van Ou Testament Teologie soos volg voorgestel word: 


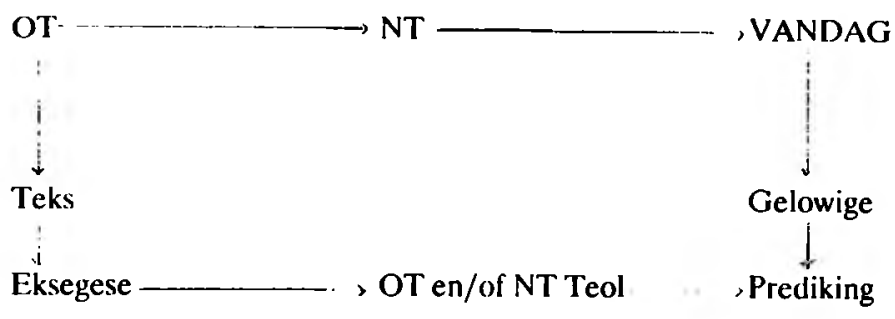

Die uitdaging aan die predikant is om 'n Ou-Testamentiese teks só uit te lê dat dit dieselfde impak het op sy hoorders as wat dit op die hoorders/lesers van destyds gehad het. In die proses om hierdie doel te bereik, is Ou Testament Teologie 'n noodsaaklike skakel in die ketting.

\section{PRAKTIESE ILLUSTRASIE}

Ter illustrasie van die teorie wat in die vorige paragrawe uiteengesit is, word enkele riglyne vir 'n preek uit Numeri 19:1-22 gegee. Hierdie teksgedeelte word doelbewus gekies omdat dit behoort tot die seremoniële gebruike van die Ou-Testamentiese kultus. Dit is van die materiaal in die Ou Testament wat baie maklik afgemaak word as sou dit nie tot die sentrum van die Skrif gereken kan word nie, maar tot die periferie ${ }^{80}$. Dit sou beskou kon word as behorende tot die seremoniële wette wat nie meer relevant is nie, maar in Christus in vervulling gegaan het en opgehef is. Die feit is egter dat hierdie teks in die Christelike kanon staan waarvan gelowiges bely dat dit die rigsnoer vir hulle lewe is. As Christene konsekwent is in die aanname, impliseer dit dat elke teks in die Ou Testament 'n boodskap vir vandag wil en kan oordra. Die vraag is nou: "Wat is die boodskap van die teksgedeelte?" en "Hoe kan Ou Testament Teologie help om dié boodskap vir vandag relevant te maak?".

Die bedoeling is nie om hier volledige eksegese te doen nie. Slegs enkele riglyne vir die eksegese en teologie word uitgewys ${ }^{81}$. Die teks bestaan uit twee groot eenhede. Verse 1-10 beskryf die voorbereiding van die as wat gebruik word as reinigingsmiddel in verskillende situasies, verse 11-22 verskillende gebruike van die reinigingsmiddel. Dit gaan spesifiek om reiniging van die onreinheid wat intree na kontak met ' $n$ lyk. Binne die konteks vervul die perikoop'n belangrike rol - veral as in ag geneem word dat Numeri 16 en 17 die werklikheid en verskriklikheid van die dood duidelik verwoord.

By die interpretasie van die gedeelte moet die volgende in gedagte gehou word: Dit gaan in Numeri 19:1-22 om 'n simboliese handeling wat verwys na 'n tweërlei werklikheid. Die eerste is die werklikheid van onreinheid en die behoefte 
om van die onreinheid verlos te word. In dié verband speel verse 11-13'n sleutelrol. Deur 'n lyk word mense onrein gemaak. Binne die konteks word die dood geteken as 'n teken van God se oordeel oor die sonde (vergelyk ook Genesis 2-3). Mense het die behoefte om van hulle onreinheid en sonde verlos te word. Die tweede werklikheid beklemtoon juis hierdie tema met die nadruk daarop dat dit God is wat reiniging van sonde en die gevolge van sonde skenk. Die simboliek van die rituele handeling moet raakgesien word. In elke aspek van die ritueel sit daar simboliek. Die rooi koei laat mens dink aan bloed, die simbool van lewe en versoening. Die feit dat sy jonk moet wees en nog nie gewerk het nie, simboliseer reinheid en lewenskrag. Seder en hissop dui op geur- en reinigingsmiddels (Psalm 51:9). Die stukkie rooi wol is ook simbool van bloed, maar miskien ook van kleding en die tente as woonplekke van destyds. Die water is natuurlik ook simbool van reiniging. Die boodskap van die gedeelte is dus dat die ritueel simbolies dui op die totale reiniging van die lewe. Die ritueel dien as teken van die herstel van die verhouding met God, van versoening.

Die gevaar bestaan dat die uiterlike handeling verabsoluteer word en dat die beginsel verlore gaan - dan word die ritueel niks anders as 'n bygeloof nie. Dit word duidelik in 'n Nuwe-Testamentiese interpretasie van bogenoemde teks, naamlik Hebreërs 9:13-14 en 13:12. Christene ken ook die gebruik van simbole om na 'n ander werklikheid te verwys. In die kerk word 'n analoë situasie beleef by die bediening van die sakramente. Die gevaar bestaan dat die sakramente bloot rituele sonder enige betekenis word. Dan word die sakramente bygeloof in plaas van sigbare, heilige tekens en seëls van die geloof (HKM Sondag 25 Vraag 66).

'n Preek uit Numeri 19 kan goedskiks by die viering van die Nagmaal gebruik word. Beide die element van die simboliese handeling en die werklikheid daaragter kan beklemtoon word. Dieselfde simboliek is teenwoordig in Numeri 19 as in die Nagmaal. Soos die as reinig van die gevolge van sonde en dood, so reinig die offer van Christus van sonde en dood. Die simbool herinner aan die werklikheid dat net God verlossing van die sonde en die dood kan skenk. Met hierdie beginsel in gedagte kan Numeri 19 relevant word binne Nuwe-Testamentiese konteks en vir die gelowige vandag. Hoewel daar afstand is tussen vandag en die teks (histories, kultureel en sosiaal), bly die beginsel staan, naamlik dat daar dinge is wat verwydering bring tussen God en mens. Hy kan egter die kloof oorbrug, want $\mathrm{Hy}$ is 'n God wat reinig van sonde en dood. Die teks lê nie op die periferie van God se genadige handelinge met die mens nie, maar verteenwoordig een (unieke) faset van God se betrokkenheid by die wêreld en by sy kinders. 
Ten spyte van die menigsverskilie oor die rol, taak en plek van Ou Testament Teologie, bly dit 'n noodsaaklike gereedskapstuk in die mondering van die moderne eksegeet. Met 'n bietjie moeite en harde werk kan die Ou Testament steeds relevant wees vir gemeentelede vandag! Predikante behoort dus moeite te doen om teologies met die teks van die Ou Testament besig te wees. Die predikant wat so te werk gaan, sal 'n brug ontdek wat hom/haar kan help om die Ou Testament weer relevant te maak vir mense wat aan die einde van die twintigste eeu leef.

\section{NOTAS:}

1 Vir 'n volledige bespreking van die onderwerp vergelyk H-J Kraus, Die Biblische Theologie: Ihre Geschichte und Problematik, Neukitchen-Vluyn 1970; J H Hayes \& F C Prussner, Old Testament Theology: Its history and development, Atlanta 1985; G F Hasel, Old Testament Theology: Basic issues in the current debate, Grand Rapids $31989,15-34$; B C Ollenburger, E A Martens \& G F Hasel, The flowering of Old Testament theology: $A$ reader in twentieth-century Old Testament theology, 1930-1990, (Sources for Biblical and Theological Study 1), Winona Lake 1992.

2 Hasel, $a w, 16-17$.

3 Gabler se intreerede is oorspronklik in Latyn gelewer onder die titel De justo discrimine theologiae biblicae et dogmaticae regundisque recte utriusque finibus. Vir die doeleindes van hierdie artikel is gebruik gemaak van die Engelse vertaling met kritiese opmerkings deur B C Ollenburger onder die titel: "An orientation on the proper distinction between Biblical and dogmatic theology and the specific objectives of each", in: Ollenburger $a w, 489-502$. Vergelyk ook Hasel, $a w, 21$.

$4 \quad$ Vergelyk F E Deist, "Relatiwisme en absolutisme: Kan dit oorkom word? Oor "Bybelse" en "dogmatiese" teologie", in: W S Prinsloo \& W Vosloo (reds), Ou Testament Teologie: Gister, vandag en môre, Pretoria 1987, 1.

5 Gabler het nie die bestaan van Bybelse Teologie as 'n afsonderlike dissipline bepleit nie, maar wel die voorrang van Bybelse Teologie as historiese dissipline gevolg deur die filosofiese verduideliking van die basiese konsepte deur die Sistematiese Teologie. Vergelyk in dié verband W S Prinsloo, "Ou Testament Teologie vandag", in: W S Prinsloo \& W Vosloo, $a w, 29$; B C Ollenburger, "From timeless ideas to the essence of religion: Method in Old Testament theology before 1930", in: Ollenburger $a w, 5$.

6 Vergelyk Hasel, $a w, 22$.

7 Feitlik die hele boek van Hasel, $a w$, word gewy aan 'n bespreking van 
hierdie drie probleemareas. 'n Nuttige oorsig oor die probleemareas word ook gegee in H G Reventlow, Problems of Old Testament Theology in the Twentieth Century (translated by J Bowden), London 1985 en J Hogenhaven, Problems and prospects of Old Testament Theology, (The Biblical Seminar 6); Sheffield 1987.

8 Vergelyk die bespreking in Reventlow, a w, 59-124.

$9 \quad$ Vir die doeleindes van die bespreking is gebruik gemaak van die Engelse vertaling van Von Rad se werk, naamlik Old Testament Theology, Volume I: The theology of Israel's historical traditions (translated by D M G Stalker), London 1975; Old Testament Theology, Volume II: The theology of Israel's prophetic traditions (translated by D M G Stalker), London 1975.

10 G von Rad, Old Testament Theology, Volume I, 108.

11 Von Rad, Old Testament Theology, Volume I, 111.

12 Hasel, a $w, 70$.

13 Hasel, $a w, 113$.

14 A H van Zyl, "Ou Testament Teologie en prediking", in: Prinsloo \& Vosloo, $a w, 54$.

15 A H J Gunneweg, Biblische Theologie des Alten Testaments: Eine Religionsgeschichte Israels in biblisch-theologischer Sicht, Stuttgart-Berlin-Köln 1993, 34-36.

16 Hasel, $a$ w, 114.

17 Vergelyk die bespreking in Reventlow, $a w, 125-133$.

18 Vir die doeleindes van hierdie bespreking is gebruik gemaak van die Engelse vertaling van Eichrodt se teologie, naamlik Theology of the Old Testament, Volume One (translated by J Baker), London 1961; Theology of the Old Testament, Volume Two (translated by J Baker), London 1967.

19 Eichrodt, Theology of the Old Testament, Volume One, 31.

20 Eichrodt, Theology of the Old Testament, Volume One, 13-14.

21 Eichrodt, Theology of the Old Testament, Volume One, 17.

22 Hasel, $a w, 119$.

23 E Sellin, Theologie des Alten Testaments, Leipzig 21936, 19.

24 L Köhler, Theologie des Alten Testaments, (Neue Theologische Grundrisse), Tübingen 1953, 12. 
25 Th C Vriezen, Hoofdlijnen der Theologie van het Oude Testament, Wageningen $51977,171$.

26 W C Kaiser, Toward an Old testament Theology, Grand Rapids 1978, 11.

27 R Smend, Die Mitte des Alten Testaments, Zürich 1970, 49.

28 W H Schmidt, Das erste Gebot. Seine Bedeutung für das Alte Testaments, München 1969, 11.

29 W Zimmerli, Old Testament Theology in outline (translated by D E Green), Edinburgh 1978, 14.

30 O Kaiser, Der Gott des Alten Testaments. Theologie des AT 1: Grundlegung, Göttingen 1993, 22.

31 S Herrmann, "Die konstruktive Restauration. Das Deuteronomium als Mitte biblischer Theologie", in: H W Wolff (hrsg), Probleme biblischer Theologie: Gerhard von Rad zum 70. Geburtstag, München 1971, 155-170.

32 S Terrien, The elusive presence: Toward a new Biblical Theology, San Francisco 1978.

33 G Fohrer, Theologische Grundstrukturen des Alten Testaments, Berlin 1972.

34 C Westermann, Theologie des Alten Testaments in Grundzügen, (Grundrisse zum Alten Testament 6), Göttingen 1978.

35 H D Preuss, Theologie des Alten Testaments Band 1: JHWHs erwählendes und verplichtendes Handeln, Stuttgart-Berlin-Köln 1991 en H D Preuss, Theologie des Alten Testaments Band 2: lsraels Weg mit JHWH, Stuttgart-Berlin-Köln 1992.

36 Preuss, Theologie Band 1, 27-30.

37 Hasel, $a w, 137$.

38 Hasel, $a w, 22-23$.

39 'n Volledige bespreking van die problematiek word weergegee in $\mathrm{A} \mathrm{H} \mathrm{J}$ Gunneweg, Understanding the Old Testament (translated by J Bowden), (OTL), London 1978.

40 Gunneweg, Understanding the Old Testament, 39.

41 Gunneweg, Understanding the Old Testament, 21-31.

42 Gunneweg, Understanding teh Old Testament, 31-35.

43 Hogenhaven, $a w, 44$. 
44 Vergelyk in dié verband F Baumgärtel, Verheissung. Zur Frage des Evangelischen Verständnisses des Alten Testaments, Gütersloh 1952; F Hesse, Das Alten Testament als Buch der Kirche, Gütersloh 1966. Vergelyk ook die bespreking van die betrokke werke in Hasel, a $w, 146-150$.

45 Vergelyk in dié verband A A van Ruler, The Christian church and the Old Testament (translated by G W Bromiley), Grand Rapids 1971; W Vischer, Das Christuszeugnis des Alten Testaments. Erster Teil: Das Gesetz, Zürich 61943; W Vischer, "Everywhere the Scripture is about Christ alone", in: B W Anderson (ed), The Old Testament and Christian faith. A theological discussion, New York 1963, 90-101. Vergelyk ook die bespreking van die betrokke werke in Hasel, $a w, 150$.

46 G von Rad, Old Testament Theology, Volume II, 364-374.

47 Westermann, $a w, 196-199$.

48 Zimmerli, $a w, 238-239$. Vergelyk ook die bespreking in Hasel, $a w, 155$.

49 Hasel, $a w, 156$.

50 Dit val buite die skopus van hierdie artikel om aandag te skenk aan die diskussie rondom die begrip "Bybelse Teologie". Daar is egter tans 'n lewendige debat oor die onderwerp in beide Ou- en Nuwe Testamentiese kringe. Meer inligting oor die debat word verstrek in J D Smart, The past, present and future of Biblical Theology, Philadelphia 1979; J Reumann (ed), The promise and practice of Biblical Theology, Minneapolis 1991.

$51 \quad$ H Gese, "Development of Biblical Theology", Horizons in Biblical Theology 3 (1981), 23-58.

52 Prinsloo, a $w, 35$.

53 B S Childs, Biblical Theology in crisis, Philadelphia 1970.

54 Childs, Crisis, 91-96.

55 Childs, Crisis, 99-107.

56 B S Childs, Introduction to the Old Testament as Scripture, London 1979, 76.

57 Childs, Introduction, 83.

58 B S Childs, Old Testament Theology in a canonical context, London 1985.

59 Childs, Theology, 1.

60 Childs, Theology, 7.

61 B S Childs, Biblical Theology of the Old and the New Testaments: Theological 
reflections on the Christian Bible, Minneapolis 1993.

62 Childs, Biblical Theology, 70-79.

63 R E Clements, Old Testament Theology: A fresh approach, London 1978.

64 R Rendtorff, "Theologie des Alten Testaments: Überlegungen zu einem Neuansatz", in: R Rendtorff, Kanon und Theologie: Vorarbeiten zu einer Theologie des Alten Testaments, Neukirchen-Vluyn 1991, 1-14.

65 Hasel, $a w, 165$.

66 Hasel, $a w, 170$.

67 J Barton, Reading the Old Testament: Method in Biblical study, London 1984, 11-19.

68 Hasel, $a w, 93 ;$ Hogenhaven, $a w, 44$.

69 Hasel, $a w, 94$; Prinsloo, $a w, 39$.

70 Hasel, $a w, 95$.

$71 \quad \operatorname{Van} \mathrm{Zyl}, a w, 63$.

72 Hasel, $a w, 139-142$.

73 Hasel, $a w, 165-167$.

74 Hasel, $a w, 171$.

$75 \quad \operatorname{Van} \mathrm{Zyl}, a$ w, 58-64.

76 Van Zyl, a w, 60-61.

77 S D Snyman, "Die verhouding tussen Ou Testament Teologie en Ou Testament eksegese", in: Prinsloo \& Vosloo, a w, 95-106.

78 Snyman, $a w, 104-105$.

79 Hasel, $a w, 171$.

80 J A Heyns, Dogmatiek, Pretoria 1978, 26-29.

81 Die volgende kommentare en ander studies word aanbeveel: P J Budd, Numbers, (WBC 5), Waco 1984; A Drubbel, Numeri, (BOT), Roermond 1963; H Jagersma, Numeri deel II, (POT), Nijkerk 1988; B Maarsingh, Numeri, (Tekst en Toelichting), Kampen 1984; J Milgrom, "The paradox of the red cow (Num XIX)", Vetus Testamentum 31 (1981), 62-72; J Scharbert, Numeri, (Die Neue Echter Bibel 27), Würzburg 1992. Die inleidings van Childs, Introduction, 190-201 en A H van Zyl, Gods Woord in mensetaal Deel 
I: Die ontstaan en boodskap van die eerste vyf boeke van die Bybel, Durban 1975, 194-212 gee addisionele inligting in verband met die opbou en boodskap van die boek. 